\title{
Проценко И.Г. \\ Влияние тампонады полости носа на мукоцилиарную транспортную систему слизистой оболочки
}

Городская больница № 1

(Россия, Ростов-на-Дону)

doi:10.18411/lj-31-03-2018-31

idsp: 000001:lj-31-03-2018-31

Носовые кровотечения (НК) занимают первое место по частоте среди спонтанных кровотечений [1]. Как правило, эти кровотечения бывают однократными, но в 4\% случаев они носят упорный, рецидивирующий характер $[2,3]$ и требуют адекватной, комплексной, патогенетически обоснованной терапии [4, 5, 6, 7].

Самым распространенным способом остановки посттравматических, послеоперационных и спонтанных НК является тампонада полости носа ввиду своей доступности и простоты $[8,9]$.

Недостатки марлевой тампонады общеизвестны: значительная болезненность при введении и удалении тампонов, активация местного фибринолиза, травма слизистой оболочки полости носа с образованием в этих участках грануляционной ткани, которая может стать источником кровотечения после удаления тампонов. Это объясняет интерес клиницистов к совершенствованию данного способа остановки НК.

Одним из важнейших показателей степени повреждения слизистой оболочки полости носа является изменение скорости мукоцилиарного транспорта $[10,11]$.

Целью нашего исследования было изучение динамики времени мукоцилиарного транспорта у больных после передней тампонады полости носа.

Материал и методы исследования. Мы исследовали изменение скорости МЦТ у 12 больных после передней тампонады носа по поводу НК. Больные были разделены на 2 группы по 6 человек: в 1 группе использована традиционная марлевая тампонада, во 2 тампонада кровоостанавливающие тампоны Smart. Кровоостанавливающие назальные Тампоны Smart предназначены для быстрой остановки носовых кровотечений. Это промышленно выпускаемые эластичные тампоны из поливинилацеталя, имеющие губчатую структуру и обработанные раствором микродисперсной окисленной целлюлозы, которая обеспечивает быстрое прекращение кровотечения из носа. При контакте с кровью назальные тампоны расширяются, принимая форму полости носа, обеспечивая гемостаз.

Время МЦТ определяли с помощью стандартного сахаринового теста в 1,3 и 5 сутки после удаления тампонов. Контрольную группу составили 23 здоровых добровольца.

Результаты и их обсуждение.

После удаления тампонов отмечено увеличение времени МЦТ у больных обеих исследованных групп, более выраженное после традиционной марлевой тампонады (таблица 1): время МЦТ у больных 1 группы составило в среднем 45,66 \pm 7 , минут, а у больных 2 группы (тампонада тампонами Smart) оно составило 21,8 $\pm 3,67$ минуту (в контрольной группе - 17,22 минут). Отмечено, что тампоны Smart не прилипают к слизистой оболочке полости носа, легко извлекаются.

Таблица 1.

Результаты исследования скорости мукочилиарного транспорта

у больных с носовым кровотечением ( \pm \pm м мин.).

\begin{tabular}{|c|c|c|c|}
\hline Способ остановки НК & $\begin{array}{c}\text { После удаления } \\
\text { тампонов }\end{array}$ & $\begin{array}{c}3 \text { сутки после } \\
\text { удаления } \\
\text { тампонов }\end{array}$ & $\begin{array}{c}5 \text { сутки после удаления } \\
\text { тампонов }\end{array}$ \\
\hline $\begin{array}{c}\text { Традиционная тампонада } \\
\text { полости носа } \\
\mathrm{n}=6\end{array}$ & $45,66 \pm 7,63$ & $37,5 \pm 4,15$ & $30,8 \pm 3,14$ \\
\hline
\end{tabular}




\begin{tabular}{|c|c|c|c|}
\hline Тампонада носа тампонами & & $14,8 \pm 1,75$ \\
Smart & $21,8 \pm 3,67$ & $18,0 \pm 2,88$ & 140 \\
\hline
\end{tabular}

На 3 сутки после удаления тампонов больные 1 группы отмечали резкое затруднение носового дыхания, наличие слизистых выделений из носа. При осмотре в полости носа отмечался значительный отек слизистой оболочки, участки ее были покрыты фибринозным налетом. Носовые ходы были резко сужены, заполнены слизистым экссудатом. После удаления экссудата производили повторный сахариновый

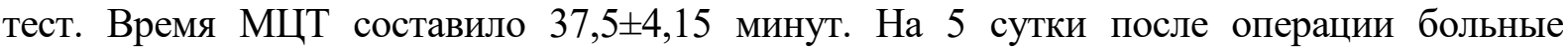
отмечали некоторое улучшение носового дыхания, но при осмотре отек в полости носа сохранялся, хотя был менее выражен. Время МЦТ уменьшилось незначительно и составило $30,8 \pm 3,14$ минут.

При осмотре больных 2 группы на 3 сутки после удаления тампонов отмечены незначительные реактивные изменения в полости носа. Носовые ходы были свободными, носовое дыхание оказалось умеренно затрудненным необходимости в применении сосудосуживающих капель не было. Время МЦТ уже на 3 сутки почти вернулось к норме и составило $18,0 \pm 2,88$ минут, а на 5 сутки - оно составило 14,8 $\pm 1,75$ минут.

Таким образом, традиционная марлевая тампонада полости носа вызывает значительное нарушение мукоцилиарного транспорта. Тампонада тампонами Smart вызывает менее выраженные изменения времени мукоцилиарного транспорта, что свидетельствует о более щадящем воздействии на слизистую оболочку полости носа. Наблюдение за больными с НК выявило преимущества тампонов Smart. Bo-первых, отмечен хороший гемостатический эффект, позволивший значительно снизить рецидивы НК после удаления тампонов. Во-вторых, реактивный отек слизистой оболочки полости носа при применении тампонов Smart был значительно меньше, чем при традиционной тампонаде.

$$
* * *
$$

1. Гаджимирзаев Г.А., Тулкин В.Н., Гаджимирзаев Р.Г. Носовые кровотечения. Аналитический обзор и собственный опыт. Рос.оторинолар. 2014. Т. 72. № 5. С. 96-110.

2. Бойко Н.В. Хирургическое лечение рецидивирующих носовых кровотечений. Рос.ринология 1999. № 2. C. 29.

3. Бойко Н.В., Шатохин Ю.В. Патогенез носовых кровотечений у больных с артериальной гипертензией. Вестник оторинолар. 2015. Т. 80. № 5. С. 41-45.

4. Бойко Н.В. Носовые кровотечения как осложнение антитромботической терапии. Российская ринология. 2011. Т. 19. № 4. С. 29-32.

5. Бойко Н.В., Колмакова Т.С. Исследование биогенных аминов у больных с носовыми кровотечениями на фоне вегетативной дисфункции. Folia Otorhinolaryngologiae et Pathologiae Respiratoriae. 2015. Т. 2. № 21. C. 27-29.

6. Бойко Н.В., Колмакова Т.С., Быкова В.В. Биохимические показатели компенсации постгеморрагической анемии у больных с носовыми кровотечениями. Вестник оторинолар. 2010. № 4. C. 13-16.

7. Киселев В.В., Трушин В.Б. Некоторые вопросы патогенеза рецидивирующих носовых кровотечений на фоне артериальной гипертензии. Рос.ринология. 2005. № 2. С. 25.

8. Волков А.Г., Бойко Н.В., Быкова В.В., Жданов В.Г. Совершенствование способов остановки носового кровотечения. Вестник оторинолар. 2010. № 4. С. 9-12.

9. Анготоева И.Б., Курлова А.В., Горносталев Н.Я. Методы остановки носовых кровотечений. Рос.ринология. 2012. Т. 20. № 3. С. 24-30.

10. Быкова В.В., Залесский А.Ю. Редкая причина рецидивирующего носового кровотечения. Рос.ринология. 2015. Т.23. № 1. С. 52-54.

11. Волков А.Г., Киселев В.В., Ерощенко А.Ю. Мукоцилиарный транспорт у больных с кокковой и гемофильной инфекцией. Рос.ринология. 2001. № 2. С. 108. 